\title{
Meeting with Max
}

It's all about control.

\begin{abstract}
John Gilbey
It was inevitable that Emma would find out about phase two of the project, but I really didn't think she would react the way she did. She called me a bastard, then a devious bastard and lastly an unethical bastard - that last one really hurt. Finally she switched approach, and waves of perfumeenhanced empathy sluiced towards me.
\end{abstract}

"You don't have to do this you know," she said quietly. "If we both leave, then the project is finished - they'd have to abandon it." Trying not to lose myself again in the ocean-blue trap of her eyes, I shook my head slowly. "I really can't afford to walk away." I didn't mention the obvious - that she was brilliant and beautiful enough to get whatever job she wanted, but one more failure would put me straight into the world of fast-food facilitation.

When she had gone, escorted home to her smallholding by an armed, leatherclad security man, I stared at the photo on the wall and wondered how it could all have gone so wrong. It showed Emma and me kneeling in a summer meadow and grinning into the camera.

Between us a fine specimen of European lynx sat on its haunches and examined the middle distance with feline hauteur. It was a stunt lynx of course, hired for the day. Ours are much bigger and never socialize.

The psychology was explained to me when we did the publicity shoot.

They needed a reason why a chunk of the Black Mountains was being set aside as a research preserve, and a project to deliver a technology-assisted rescue lynx - that could search out lost children and other worthy targets - was just right. This was bullshit, of course. The main deliverable of the programme was a new line in assassination tools.

Think about it: a lynx is resourceful, almost silent, preys on things up to the size of deer and can disappear without trace for weeks at a time. Implant some symbiotic bioactive technology that grows to form part of the nervous system and you can control its actions by satellite from anywhere. It is politically safe too:
"Murder? Surely not, people get killed by wild animals all the time..."

Emma and I were teamed up to do the training. She would lounge in the office using the command-system headset to read the sensory inputs from the animal and send it subliminal hints on where food and shelter might be found, using her undoubted powers of persuasion to build its reliance on the alien thoughts. Once it accepted them, Emma turned the

I had to crunch across country by Land Rover until I picked up his signal. He had reverted to instinct and was trying to lose himself in a pine forest - I chased him on foot, cursing satellite technology and feeling his mind through the portable kit. As the day wore on we got increasingly hungry and tired: in the dusk, snow began to fall.

Shaking with cold and exertion, I struggled down the hillside. At the edge of the trees was a field of sheep, beyond it a farmhouse. Hunger had grown to a nauseating physical pain - like a bad migraine. Max was close now and I could sense him coldly planning the attack. I felt the slow, silent feline approach - head close to the ground - then the adrenaline rush and the dash to the target. The neck bite brought the lamb down cleanly; tearing at its throat splashed steaming blood onto the snow - it felt hot running down my face as I ripped at the flesh with greedy satisfaction.

I heard a yell close by, then something heavy hit me on the side of the head. I struck out wildly and connected with something - a body sprawled backwards onto the snow. Pouncing on it, I wrenched the head back and

animal over to me for phase two - which only I knew was based on negative reinforcement. I used the system to show it what happened when it ignored me: bad dreams, pain, sensations of fear and panic. If it wanted to avoid these things it must obey me. Specifically, it had to attack on command the figure whose pictures I put in its head - a foreign concept to an animal that killed only when hungry.

Her resignation came just at the wrong time. We had an important target coming up - some tribal warlord in a mountain stronghold - but we didn't have a good candidate available. Emma had been only halfway through training Max, but I took him over anyway and gave him a crashcourse in obeying orders - he fought back, refusing to attack the test targets. I guess I must have pushed him too hard - he broke out of the preserve and went on the run.

If the satellite downlink hadn't failed I could have tracked him easily, but instead my jaws went down for the killing bite.

It was her perfume that saved her. As if waking from a nightmare I saw Emma's eyes looking up at me. There was no fear in her face - just loathing, hatred and profound revulsion. Horrified beyond words at what I had done, I backed away and stumbled into the trees.

I should have guessed that I would lose if I challenged Max on his own ground - but I had no idea that the command interface could work in both directions. Just before I tore off the headset I caught a snatch of cold contentment, so perhaps I have taught him to enjoy revenge. Far away I can hear the security team crashing through the undergrowth towards me, but I'm too tired to run any further. So I'm sitting here in the snow - remembering Emma's face, feeling the caked blood in my beard and considering my future. Part of me hopes that Max will find me before they do.

John Gilbey insists that this is a work of fiction. His nightmares are his own. 